\title{
Role of Knowledge Management in Strengthening Corporate Governance in the Organisation
}

\author{
LAXMINARAYANA MAROLI \\ Asst. Prof. Department of Commerce \& Management \\ Acharya Bangalore B. School, Bangalore \\ Andrahalli main road, Andrahalli, Bengaluru \\ Research Scholar, Dept. Of Corporate Secretaryship, Alagappa University
}

\begin{abstract}
Knowledge is an asset for every individual and organisation, Knowledge includes set of know how, process technology, marketing strategy, accounting system, managerial skills etc. there is a great deal in the corporate and business world that information and knowledge can be vital tools in the organisation. Fairness, transparency, responsibility and accountability is the basic principles of corporate governance. During last 25 years business world had grown rapidly. Simultaneously many corporate failures and scams also being happening all over the world including India. So there is a need of strict corporate governance code implementation in every organisation. So effective knowledge development in this regard is very much essential for the success of corporate governance. Knowledge regarding basic principles of corporate governance, sustainability in business, Corporate Social responsibility is essential to all responsible corporate members like any other marketing and technical knowledge. This research paper is based on secondary data and primary data. In this paper researcher having main objective to identify the role of knowledge management in effective corporate governance in the organisation.
\end{abstract}

Keywords: Corporate Governance, Sustainable development, Knowledge Management, Corporate Committee.

DOI: $10.7176 / \mathrm{IKM} / 9-11-01$

Publication date: December $31^{\text {st }} 2019$

\section{INTRODUCTION}

Knowledge is an asset for every individual and organisation, Knowledge includes set of know how, process technology, marketing strategy, accounting system, managerial skills etc. there is a great deal in the corporate and business world that information and knowledge can be vital tools in the organisation. Knowledge management is very important tool in the organisation Knowledge management is one of the competitive advantage of any organisation. In the present day world organisations with high knowledgeable skilled and talented manpower will succeed in their business and commercial transitions. Updating of knowledge and skills is very much essential requirement for every personnel of the various department functions in the organisation for organisation's success.

Board of directors are the ultimate authority in the corporate companies, who is responsible for company's good governance for the purpose of achieving organization's success. Board of Directors, Managing Director, Chief financial Manager, Independent Directors, Whole Time Directors, Company Secretary, Auditors are important Key Managerial Personnel who responsible and accountable for good governance, corporate social responsibility, sustainable development in the organisation. These member expected to have relevant knowledge in their function and in legal, technical, marketing, industry for achieving corporate objectives. These key managerial personnel required to gain relevant knowledge of the corporate governance, legal, ethics, corporate social responsibility, industry, technology, and other business environment through proper training and knowledge exchange series program for the better corporate governance for sustainable growth in the business.

\section{Objectives:}

- To know Knowledge Management system in the corporate organisation.

- To know the corporate Governance system as per Company's Act.

- To know the role of knowledge management on achieving good corporate governance for becoming successful organisation.

- To know the role of knowledge management in enhancing board performance.

- To know the significance of knowledge management in sustainable business development.

\section{Methodology of the Study:}

Methodology of this research study was based on the Secondary data and Primary data. Secondary data which is collected from various sources like annual reports published by the company ,company website, research articles published in newspapers, journals, magazines, data published in Ministry of Corporate Affairs, Research 
papers published in online journals and other internet sources.

The primary data was collected through survey method by distributing questionnaire to respondents. Researcher had distributed Questionnaire to Academicians, Corporate Managers, Officers, Directors and working executives, and post graduate students. The Sample size selected was 120 and researcher has followed convenient sampling method for this research purpose. The hypotheses are framed to analyse the significant role of company's Knowledge Management System and Corporate Governance and Company's KM system and enhancement of Board performance and Company's KM system and Sustainability in Business. Researcher has used simple percentage system for analysing the data for this research purpose. Researcher have created respondents group like Corporate managers/ officers and Academicians for the purpose of finding significance/ insignificance status of a selected issues or question. For analyzing this researcher has used The chi-square test (statistical tool) for the purpose of arriving significance or insignificance status of a given question.

\section{Hypothesis of the Study:}

- H1 - There is a significant role of Company’s KM system on Corporate Governance for Organisations' success

- H0 - There is no significant role Company's KM system on Corporate Governance for Organisations' success.

- H1- There is a significant role of Company's KM System on enhancement of Board performance

- H0 - There is no significant role of Company's KM System on enhancement of Board performance.

- H1 - there is a significant role of Company's KM System on Corporate governance and Sustainability in Business

- H0- there is no significant role of Company's K M System on Corporate Governance and Sustainability in Business

\section{Literature Review}

Different experts and researchers have defined knowledge management in various mode. Knowledge management is the capability to manage knowledge such as gathering internal and external knowledge of organisation, converting them to new idea or strategy and applying them and protecting them (gold et.al, 2001)

Lytras et. Al (2002) defined knowledge management as a systematic, explicit and application of knowledge that will help the organisations to maximise the organisations knowledge - related effectiveness and returns from the knowledge assets.

Research done by Ibrahim and Reid (2009) stated that knowledge management is also important for the organisations to create a sustainable competitive advantage and improve business processes. The business process can be improved by reducing the processing time as the individuals can share their best practices. Besides, during the conversations and discussion among individuals, it can generate valuable knowledge which can be shared among each other. Knowledge management can also enhance the organisations' operational activities.

La Porta et al. (2000) defines corporate governance " as a set of mechanisms through which external investors guard themselves against expropriation by the internal ones as managers and share holders"

Holmstrom and Kaplan (2001) defines corporate governance as " the mechanisms through which companies and their managers are directed, where such mechanisms frequently are directed in the forms of mergers, takeovers, executive stock options, involvement of board of directors and share holders"

The need to align KM strategy with organisation strategy was identified as critical to the success of KM (oluikpe 2012; Gao, Li and Clarke, 2008, du Plesssis (2007) express their opinion that an organisation KM strategy is supposed to create an understanding of the organisation's KM resources and where they reside; articulate the role of Knowledge in value creation; and comprise a number of integrated projects or activities phased over time including quick wins as well as long term benefits.

\section{Knowledge Management}

Knowledge management is a strategy and methodology for business success. Knowledge Management is a newly coming up business strategy that has knowledge within the framework of an organisation as its focus. Knowledge management is ultimate strength and competitive advantage for modern globalised business world. Knowledge management involves people, technology and processes. Knowledge is considered as asset for the organisation. Knowledge organisation gets knowledge from various sources, like customer knowledge, product knowledge, financial knowledge, personnel practice knowledge, direction knowledge, legal knowledge, compliance knowledge, technical knowledge, administration knowledge etc.

Organisation require knowledge not only from technical side, also from non technical side also. Technical side knowledge may be related to plant lay out to technical know-how, building, estate, computers, software, machines, process, raw materials, design, packing, quality etc. Non technical knowledge may be related to 
business regulations, organisation structure, environmental laws, employment laws, HR policy, advertising, taxation, competitive firms, distribution channels, transportation system, product line, pricing, corporate governance codes, corporate laws, macro environment factors etc. Therefore knowledge in all aspect is very much important for the purpose of achieving competitive advantage for the organisation and to avoid corporate governance failures. Every organisation required to take necessary strategy for the development of knowledge of personnel including managers directors in the organisation.

\section{Corporate Governance system}

Since 1990, the Corporate Governance system was initiated in India By the SEBI through its Listing Agreement which was applicable to the listing companies only.

OECD Corporate Governance principle states that the allocation of rights and responsibilities in between different players in the organisation or corporate companies such as, the Board of Directors, Key Managerial Personnel, Shareholders and other stake holders reveals the rules and procedures for making policies and decisions on corporate administrative and controlling affairs of the organisation.

According of Sir Adrian Cadbury " Corporate Governance is the system by which companies are directed and controlled." Corporate governance may be defined as the broad range of policies and ethical practices which are adopted by an organisation in its dealing with the stake holders.

Corporate Governance is the system in which corporate companies operate including the rules, regulations, policies and standards for accountability, transparency and general corporate combination. The important components of good corporate governance are: Transparency, Accountability, Disclosure, Equity, Fairness, Rule of Law and Participatory.

Need for corporate Governance:

Corporate Governance practices are very much essential in the present day business world due to following reasons:

- Share holders are spread over global level

- Changing ownership structure

- Corporate scams and scandals

- Greater expectation of society and corporate sector

- Hostile takeovers, mergers.

- Heavy increase in top management compensation

- Globalisation effects.

\section{Role of SEBI in corporate governance:}

SEBI issued certain guidelines on corporate governance, which are required to be incorporated in listing agreement between company and the stock exchange.

Some of the important guidelines issued by SEBI is listed below:

- Board of directors of a company shall have an optimum combination of executive and non executive directors

- In case non executive chairman at least $1 / 3^{\text {rd }}$ of the board should comprise of independent directors and in case of executive directors $1 / 2$ of the board comprise independent directors

- The company shall form an independent audit committee whose constitution would be- it shall have minimum of 3 members, all being non executive directors with the majority of being independent, and at least one director having financial and accounting knowledge, Chairman of the committee shall be an independent director.

- The following disclosures on the remuneration of directors shall be made in the section on the corporate governance of the Annual Report.

i) All elements of remuneration package of all the directors i.e., salary, benefits, bonus, stock option, pension etc.

ii) Details of fixed component and performance linked incentives, along with performance criterion.

- Board meetings shall be held at least four times in a year, with maximum gap between 4 months.

- A management discussion and analysis report to the shareholders containing discussion on the matters like opportunity, threats, risks and concerns.

- There shall be a separate section on corporate Governance in the annual report of the company with details on corporate governance

- The company shall obtain a certificate from the auditors of the company regarding the compliance of conditions of CG. The certificate shall be annexed with the directors reports sent to the shareholders 
and also sent to the stock exchange

Principles of corporate governance:

- Fairness

- Transparency

- Accountability

- Responsibility

\section{Board committees}

As per corporate governance regulations company required to form following board committees for the purpose of better and successful working of corporate governance system in the organisation. Each committee is responsible and accountable for allotted functions in the organisation.

- Audit committees

- Nomination committee

- Remuneration committee

- Risk committee

- CSR committee

\section{Reasons for corporate governance failure:}

- Fraudulent accounting practices

- Poor internal control

- Non adherence of corporate governance norms

- Mismanagement of funds

- Unqualified and inexperienced members of the board

- Questionable ethics

- Non disclosure of mandatory items

- Nepotism and favouritism

- Poor management.

The Board is the ultimate authority of the company and therefore they have greater accountability and responsibility to the stake holders. Company required to include members of the board having expertise, specialisation and good practical knowledge in administration, accounts, marketing, finance, legal and regulatory framework. Present day business is very much complex in nature. Directors required to take perfect decisions in this complex and tough situations for the survival of the organisation. Therefore directors required to posses knowledge in multiple fields. Company required access the training requirement of the directors, senior management and functional management executives. Knowledge is considered as power, through this board of directors can implement corporate governance policies and get success in corporate governance. So corporate governance success can be achieved through knowledge management. Organisation members including directors, managers, audit committee, risk committee, remuneration committee, nomination committee required to update various types of knowledge pertaining to their company, specialisation and industry as well as macro economic sector from time to time. If all corporate members required to gain perfect knowledge then corporate failures and scams can be reduced and controlled. Organisation require to gain knowledge and experience, optimise and enhance their usefulness and make them available to improve decision making and implementation of decision and control. Knowledge managements reduces the mistakes of the past. Knowledge management underpins organisational learning and maturity.

\section{Data Analysis and findings}

Table 1A

\begin{tabular}{|l|c|c|c|c|c|}
\hline Details & $\begin{array}{c}\text { very } \\
\text { low }\end{array}$ & low & moderate & $\begin{array}{c}\text { high } \\
\text { very } \\
\text { high }\end{array}$ \\
\hline $\begin{array}{l}\text { Awareness about Corporate Governance System in the } \\
\text { organisation As per companies'Act }\end{array}$ & $5 \%$ & $16 \%$ & $41 \%$ & $30 \%$ & $8 \%$ \\
\hline
\end{tabular}

Source : primary data

As per above data awareness among respondents about CG system is less only $38 \%$ of respondents knowing about CG system applicable to the organisation. 
Table 1B

\begin{tabular}{|l|c|c|}
\hline \multicolumn{1}{|c|}{ Group } & insignificant & significant \\
\hline Corporate Managers/officers & 31 & 27 \\
\hline Academicians & 43 & 19 \\
\hline Total & 74 & 46 \\
\hline
\end{tabular}

The chi-square statistic is 3.2075. The $p$-value is .073302 . This result is not significant at $p<.05$. The chi-square statistic with Yates correction is 2.5699. The $p$-value is .108916. Not significant at $p<.05$.

As per above table awareness of CG System among academicians and corporate executives are not significant they are in the same line with regard to awareness of CG system

Table 2A

\begin{tabular}{|l|c|c|c|c|c|}
\hline Details & $\begin{array}{c}\text { very } \\
\text { low }\end{array}$ & low & moderate & $\begin{array}{c}\text { high } \\
\text { very } \\
\text { high }\end{array}$ \\
\hline $\begin{array}{l}\text { Involvement in Corporate Governance system /process in the } \\
\text { organisation. }\end{array}$ & $16 \%$ & $32 \%$ & $27 \%$ & $18 \%$ & $7 \%$ \\
\hline
\end{tabular}

Source : primary data

As per above table major part or respondents have less involvement in the CG process . $25 \%$ people only have high level of involvement in CG system in the organisation

Table 2B

\begin{tabular}{|l|c|c|}
\hline \multicolumn{1}{|c|}{ Group } & insignificant & significant \\
\hline Corporate Managers/officers & 52 & 17 \\
\hline Academicians & 38 & 13 \\
\hline Total & 90 & 30 \\
\hline
\end{tabular}

The chi-square statistic is 0.0114 . The $p$-value is .915094 . This result is not significant at $p<.05$. The chisquare statistic with Yates correction is 0.0114. The $p$-value is .915094. Not significant at $p<.05$.

As per above table involvement in CG system is insignificant as both group have same line of involvement pattern. (author calculation) defined knowledge management in several ways.

Knowledge management is the capability to manage knowledge such as gathering internal or external knowledge of organizations, converting them to new idea or strategy and applying them and protecting them (Gold et al., 2001). Lytras et al. (2002) defined knowledge management as a systematic, explicit and application of knowledge that will help the organizations to maximize the organizations' knowledge-related effectiveness and returns from the knowledge assets.

Different experts or researchers have defined knowledge management in several ways.

Knowledge management is the capability to manage knowledge such as gathering internal or external knowledge of organizations, converting them to new idea or strategy and applying them and protecting them (Gold et al., 2001). Lytras et al. (2002) defined knowledge management as a systematic, explicit and application of knowledge that will help the organizations to maximize the organizations' knowledge-related effectiveness and returns from the knowledge assets.

Table 3A

\begin{tabular}{|l|c|c|c|c|c|}
\hline Details & $\begin{array}{c}\text { very } \\
\text { low }\end{array}$ & low & moderate & $\begin{array}{c}\text { high } \\
\text { very } \\
\text { high }\end{array}$ \\
\hline $\begin{array}{l}\text { Significance of knowledge management in achieving best results } \\
\text { with respects to better decision making }\end{array}$ & $0 \%$ & $2 \%$ & $16 \%$ & $59 \%$ & $23 \%$ \\
\hline
\end{tabular}

Source : primary data

As per table no. $1,59 \%$ respondents say that significant of knowledge management in achieving best results in decision making is high and $23 \%$ respondents say that it is very high. Therefore researcher can clued that Knowledge management system is very much essential for every organisation for better results and decision making.

Table 3B

\begin{tabular}{|l|c|c|}
\hline \multicolumn{1}{|c|}{ Group } & insignificant & significant \\
\hline Corporate Managers/officers & 15 & 55 \\
\hline Academicians & 11 & 39 \\
\hline Total & 26 & 94 \\
\hline
\end{tabular}

The chi-square statistic is 0.0056 . The $p$-value is .940287 . This result is not significant at $p<.05$. The chisquare statistic with Yates correction is 0.0224 . The $p$-value is .880908 . Not significant at $p<.05$

As per above table both group think in the same line of significance level therefore the result is insignificant. (author calculation) 
Table 4A

\begin{tabular}{|c|c|c|c|c|c|}
\hline Details & $\begin{array}{c}\text { strongly } \\
\text { disagree }\end{array}$ & disagree & neutral & $\begin{array}{c}\text { agree } \\
\text { strongly } \\
\text { agree }\end{array}$ \\
\hline $\begin{array}{c}\text { Knowledge management will improve good } \\
\text { governance and reduce corporate failures }\end{array}$ & $1 \%$ & $1 \%$ & $16 \%$ & $57 \%$ & $25 \%$ \\
\hline
\end{tabular}

Source : primary data

As per table no 2, 57\% respondents agree that knowledge management will improve good governance and reduce corporate failures and $25 \%$ respondents strongly agree this statement. Therefore researcher will agree that knowledge management in the organisation will improve corporate governance and its is necessary for avoiding corporate failure.

\begin{tabular}{|l|c|c|}
\hline \multicolumn{1}{|c|}{ Group } & insignificant & significant \\
\hline Corporate Managers/officers & 15 & 55 \\
\hline Academicians & 10 & 40 \\
\hline Total & 25 & 95 \\
\hline
\end{tabular}

The chi-square statistic is 0.0361 . The $p$-value is .849329 . This result is not significant at $p<.05$. The chisquare statistic with Yates correction is 0.0014 . The $p$-value is .969692 . Not significant at $p<.05$

With reference to the above table both group will have the same level of opinion with reference to significance of the give problem(author calculation)

\begin{tabular}{|l|c|c|c|c|c|}
\hline Details & $\begin{array}{c}\text { Strongly } \\
\text { disagree }\end{array}$ & disagree & neutral & $\begin{array}{c}\text { agree } \\
\text { strongly } \\
\text { agree }\end{array}$ \\
\hline $\begin{array}{c}\text { Knowledge management will improve } \\
\text { board efficiency and performance }\end{array}$ & $1 \%$ & $1 \%$ & $10 \%$ & $54 \%$ & $34 \%$ \\
\hline
\end{tabular}

Source : primary data

As per table no. 3, 54\% respondents agree that knowledge management will improve board efficiency and performance and 34\% respondents strongly agree this statement. Researcher in this regard conclude that knowledge management is essential for improving board success to avoid corporate governance failure.

Table 5B

\begin{tabular}{|l|c|c|}
\hline Group & insignificant & significant \\
\hline Corporate Managers/officers & 9 & 60 \\
\hline Academicians & 7 & 44 \\
\hline Total & 16 & 104 \\
\hline
\end{tabular}

The chi-square statistic is 0.0118 . The $p$-value is .913483 . This result is not significant at $p<.05$. The chisquare statistic with Yates correction is 0.0266 . The $p$-value is .870542 . Not significant at $p<.05$

As per above table also both group under study have the same observation towards given question. (author calculation)

\begin{tabular}{|l|c|c|c|c|c|}
\hline Details & $\begin{array}{c}\text { Table 6A } \\
\text { disagree }\end{array}$ & disagree & neutral & $\begin{array}{c}\text { agree } \\
\text { strongly } \\
\text { agree }\end{array}$ \\
\hline $\begin{array}{l}\text { Effective knowledge management will } \\
\text { help in achieving good governance and } \\
\text { gaining good will }\end{array}$ & $0 \%$ & $0 \%$ & 14 & $54 \%$ & $32 \%$ \\
\hline
\end{tabular}

Source : primary data

As per table no. 4, 54\% respondents agree that knowledge management will help in achieving good governance and gaining goodwill , 32\% respondents strongly agree this point. So researcher can conclude that knowledge management is essential strategy for achieving good governance to avoid corporate failures.

\section{Table 6B}

\begin{tabular}{|l|c|c|}
\hline Group & insignificant & significant \\
\hline Corporate Managers/officers & 12 & 57 \\
\hline Academicians & 9 & 42 \\
\hline Total & 21 & 99 \\
\hline
\end{tabular}

The chi-square statistic is 0.0013 . The $p$-value is .970924 . This result is not significant at $p<.05$. The chisquare statistic with Yates correction is 0.0427 . The $p$-value is .836362 . Not significant at $p<.05$

As per above table also both group under study have the same observation towards given question. (author calculation) 
Table 7A

\begin{tabular}{|l|c|c|c|c|c|}
\hline Details & $\begin{array}{c}\text { strongly } \\
\text { disagree }\end{array}$ & disagree & agree & $\begin{array}{c}\text { strongly } \\
\text { agree }\end{array}$ \\
\hline $\begin{array}{l}\text { Good corporate governance supported by knowledge } \\
\text { management helps to achieving sustainability in } \\
\text { business }\end{array}$ & $0 \%$ & $2 \%$ & $14 \%$ & $52 \%$ & $32 \%$ \\
\hline
\end{tabular}

Source : primary data

As per table no 5, 52\% respondents agree with good governance supported by knowledge management will help organisation in achieving sustainability in business and $32 \%$ respondents have strongly agreed this point. So researcher has conclude that Strong Corporate governance and knowledge management is essential for achieving sustainability in business.

Table 7B

\begin{tabular}{|l|c|c|}
\hline Group & insignificant & significant \\
\hline Corporate Managers/officers & 13 & 56 \\
\hline Academicians & 10 & 41 \\
\hline Total & 23 & 97 \\
\hline
\end{tabular}

The chi-square statistic is 0.0111 . The $p$-value is .915932 . This result is not significant at $p<.05$. The chisquare statistic with Yates correction is 0.0166 . The $p$-value is .897345 . Not significant at $p<.05$

As per above table also both group under study have the same observation towards given question regarding achieving sustainability in business of the organisation. (author calculation)

\section{Findings:}

- Through this research study researcher has found that, there is significant role of knowledge management and corporate governance for corporate success. So alternate hypothesis is accepted and null hypothesis in rejected. Both Corporate management group and Academicians groups have the same level of opinions.

- Also there is a positive role of knowledge management system in improving board performance. So alternate hypothesis is accepted and null hypothesis is rejected. Both Corporate management group and Academicians groups have the same level of opinions

- Also there is a positive role of knowledge management system, corporate governance in achieving sustainability in business. So alternate hypothesis is accepted and null hypothesis is rejected. Both Corporate management group and Academicians groups have the same level of opinions

- Government agencies also required to implement various corporate regulations for strictly for the purpose of avoiding corporate failures.

- Every organisation required to make necessary arrangement for the purpose of update the knowledge of organisational members including directors, managers and various board committees for purpose of effective implementation of corporate governance.

- Like any code of conduct, corporate governance code must be known by all responsible directors and managerial personnel. He is required to update these code of corporate governance from time to time. Researcher has identified that many managerial personnel and directors not giving sufficient importance for knowledge related to corporate governance system and implementation.

\section{Conclusion}

Knowledge is asset for every organisation. Creating knowledge through innovation, collection and preserving knowledge and developing knowledge, managing knowledge in the organisation for the purpose of getting competitive advantage in the business. Technologically strong organizations will survive for a long term in the business. Knowledge is a power for every individual and organisation. Knowledge management among Board and KMP also required like any other department. Company's Act 2019 lays down number of regulations. Systems, code of conduct for BOD and KMP as well as committees. So every one required to update and gain these legal knowledge along with their business and technical knowledge. Knowledge Management playing key role in the functions of all the department of the organisation including BOD in attaining corporate success, reducing corporate failures, gaining goodwill and sustainability in business.

\section{References}

1) H.R. Machiraju (2018) Corporate Governance HPH, pp13-26

2) Funmilola Olubunmi Omotayo (2015) “Knowledge Management as an important tool in Organisational Management: A Review of Literature” pp 1-24 http://digitalcommons.unl.edu/libphilprac

3) Srinivasan, P., and Srinivasan, V., 2011. Status of Corporate Governance Research on India: An Exploratory 
Study.IIM Bangalore Research Paper, (334).

4) Sinha, P., and Singhal, A., 2012.A note on Corporate Governance in Public Sector Undertakings in India. [Online] Available at: <http://mpra.ub.uni-muenchen.de/41038/>

5) Bhardwaj, N., and Rao, B.R., 2014.Corporate Governance Practices In India - A Case Study. Asia Pacific Journal of Research,

6) .S. Siva Shree and ,M. Kannappan, "A Study of Corporate Governance under the Companies Act, 2013" Volume 119 No. 17 2018, 957-967 ISSN: 1314-3395 (on-line version) url: http://www.acadpubl.eu/hub/ Special Issue http://www.acadpubl.eu/hub/

7) Yogesh Sharma, Implications of Companies Act, 2013 Governance, Grant Thornton India LLP report 2013.

8) Vaish Associates Advocates - " Corporate Governance Frame work in India " online article $8^{\text {th }}$ January 2016

9) Shagunbahl, "Corporate Governance under the Companies Act, 2013, article dated Oct 10, 2017, Pleaders intelligent legal solutions articles.

10) Colin Ting Si Xue (Corresponding author) "A Literature Review on Knowledge Management in Organizations Research in Business and Management ISSN 2330-8362 2017, Vol. 4, No. 1 pp $30-41$

11) Funmilola Olubunmi Omotayo " Knowledge Management as an important tool in Organisational Management A Review of Literature" (2015). Library Philosophy and Practice (e-journal). 1238. http://digitalcommons.unl.edu/libphilprac/1238

12) Iram Rasheed, Knowledge Management as a Strategy \& Competitive Advantage: A Strong Influence to Success, a Survey of Knowledge Management Case Studies of Different Organizations , Information and Knowledge Management www.iiste.org ISSN 2224-5758 (Paper) ISSN 2224-896X (Online) Vol.5, No.8, 2015

13) Knowledge Management for the Global Corporation, The Global CEO Report 1999

14) Elias M Awad \& Hassan Ghaziri, Knowledge Management - Pearson 2007 edn. Pp 1-50

15) Christine A Mallin - Corporate Governance - Oxford - enn 2016. Pp 1-60

16) Dr. D.P. Verma, Raj Kumar, "Relationship between Corporate Social Responsibility and Corporate Governance", IOSR Journal of Business and Management, (IOSRJBM) ISSN: 2278-487X Volume 2, Issue 3 (July-Aug. 2012), PP 24-26 www.iosrjournals.org.

17) KEERTHEVASAN. V, "ROLE OF SEBI IN CORPORATE GOVERNANCE “ International Journal of Pure and Applied Mathematics Volume 120 No. 5 2018, 217-229 ISSN: 1314-3395 (on-line version) url: http://www.acadpubl.eu/hub/ Special Issue.

18) Knowledge Management article published in https://www.apm.org.uk.

19) Raksha Talathi "Corporate Governance in India: Concept, Needs and Principles" article published in www.yourarticlelibrary.com 